\title{
A chronological exploration of the evolution of housing typologies in Gulf cities
}

\author{
Adel M. Remali', Ashraf M. Salama ${ }^{1 *}\left(\mathbb{0}\right.$, Florian Wiedmann ${ }^{1}$ and Hatem G. Ibrahim²
}

\begin{abstract}
This paper traces the evolution of housing typologies in four major cities in the Gulf region, namely Doha, Dubai, Abu Dhabi and Manama. The study reviews the formation and historical events in the region, which had a significant impact on new social as well as economic realities and consequently evolving housing types during the last two centuries. The methodological approach is based on reviewing a number of case studies representing local housing typologies throughout distinctive historic periods which were categorized in four periods: the post-nomadic, traditional, modern, and contemporary. The main objective is to identify the process of transformation by applying a comparative assessment of the different periods in order to examine continuities or ruptures between them. Thus, particular layout elements were analysed and compared. Conclusions are drawn to underline contemporary challenges while offering projections for future housing typologies in the selected cities and other similar ones.
\end{abstract}

Keywords: Contemporary urbanism, Gulf cities, Housing transformation, Housing production, Residential architecture

\section{Background}

Housing transformations worldwide are the result of major demographic and socio-economic changes in addition to technological advancements and sociopolitical interventions. In the case of vernacular settlements housing has always been a direct expression of the state of know-how of construction techniques, available local construction materials as well as local climatic and cultural conditions (Turner 1976). Consequently, it is argued that the community itself and its particular environmental conditions are the producers of housing typologies, which have usually led to a high degree of continuity of architectural styles and representation in spite of a high level of individuality due to missing construction standards. Today, vernacular settlements and their rather homogenous housing typologies can still be found and studied in the case of preserved pre-industrial medieval settlements in Europe as well as in remote rural areas in the developing world, where colonial influences

\footnotetext{
*Correspondence: asalama@gmail.com; ashraf.salama@strath.ac.uk ${ }^{1}$ Department of Architecture, University of Strathclyde, Level 3, James Weir Building, 75 Montrose Street, Glasgow G1 1XJ, UK Full list of author information is available at the end of the article
}

have been limited, such as Yemen or Mali (Lauber et al. 2011).

In the case of settlements, which became important centres of political power, the extensive growth and subsequent exposure to new construction materials and techniques in addition to increasing top-down political intervention led to first new development tendencies. Ancient examples can be found in the case of Greek as well as Roman settlements following rigid infrastructural grids and standardized housing sizes as well as layouts (Owens 1992). However, only after the industrial revolution, the vernacular bottom-up drivers of the general housing evolution were completely replaced by an increasingly standardized construction industry which was coupled with the emergence of modern urban planning that began to implement clear and rigid housing policies (Hall 2002). The top-down planning and administration of housing development enabled more efficient housing supply and first mass housing schemes, but consequently a diminishing influence of local communities.

The experience of early industrial cities during the nineteenth century has resulted in the emergence of the "Garden City" movement, which was initiated by Ebenezer Howard (1898). Such a movement can be viewed as 
a direct reaction to the missing but desired link between residents-individually or collectively, and their private homes. The invention and industrial mass production of the car has been the precondition of enabling one of the biggest housing revolutions in the twentieth century, the new ideal of single-family dwellings in a green suburban environment along the peripheries of major cities (Duany et al. 2010). In spite of the general homogeneity of the newly emerging suburbs and the common practice of mass housing projects, the individual needs and wants of higher-income groups have been reflected in ground floor plans and major design elements leading to a new phase of individual identification between families and their homes.

Due to the on-going fragmentation of urban areas, the resulting traffic congestion as well as limited lifestyle choices in suburban settings, a new housing tendency has emerged at the end of the twentieth century, commonly referred to as gentrification and the rebirth of downtown areas in the Global North. While residents in developed countries rediscovered city centres as potential homes, cities in the Global South have witnessed the increasing phenomenon of gated communities. The analysis of the historic housing evolution in particular regions can provide in-depth insights on how living standards as well as lifestyles transformed and how contemporary housing conditions reflect the various historic and cultural roots. A review of any housing transformation therefore aims to enhance awareness and thus enables a conscious approach in designing future houses.

Since the Gulf region is a very particular case that integrates typical development tendencies from both the Global North and the Global South (Salama and Wiedmann 2013), this paper is based on studying housing transformations in four Gulf cities, namely Doha, Dubai, Abu Dhabi and Manama. In this paper, the four major historic periods of housing evolution in the selected cities are critically analysed. Based on identifying typical types that represent different phases of development a comparative assessment is conducted to explore discontinuities and gaps and/or continuities and overlaps of housing development and to discuss alternative approaches for the development of future housing typologies in the Gulf region.

\section{Methodological approach}

The crux of the examination is to explore the transformation of the dwelling's layout and its spatial interior spaces over time in terms of the composition and functions of the housing unit. The typological analysis places emphasis on key specific qualities of the dwellings while identifying their characteristics in order to establish differences that can be utilized for typological classification. The investigation of typological evolution and transformation in the selected four Gulf cities adopts a multi-layered methodological approach that involves the following two preparatory procedures:

- Review of theoretical underpinnings and conceptual tenets on housing typologies; and

- Identification of four historic periods that have resulted from various events with significant impacts on socio-economic and socio-cultural realities.

These two procedures offer a substantial base for conducting a typological analysis as a third procedure. With the purpose of carrying out the typological analysis of housing evolution in the Gulf region, the third procedure is devised as a sampling approach. Eighteen samples of housing types were selected from a wide variety of houses that represent successive historic eras in each of the selected cities. After a detailed study of all samples, six examples are selected to represent the four historic periods that are categorized as: post-nomadic, traditional, modern and contemporary. The first two periods are represented by a singular housing model, which is considered to be a predominant housing typology in that era. Four models, two models each, represent the second two periods.

Beside the singular house or villa model, multi-storey buildings were introduced as residential modern and contemporary models. The selection of these models is based on the internal layout characteristics of the housing typology in Gulf cities. Twenty-six models of residences are selected from four major cities in the region. These samples primarily represent the majority of housing models of formally designed dwellings during the last century. Notably, not all the models were covered in this study and therefore it cannot be considered exclusive (Fig. 1).

For an effective comparative analysis the reproduction of scaled floor plans was a necessary procedure. The architectural floor plans reveal the typological transformation of the housing production and the way in which the residential units were designed in each period. The dwelling's layout is analytically defined, described and its evolution is traced within the selected historic eras.

The preceding procedures resulted in a series of outcomes in the form of observations and interpretations with respect to the typological housing evolution in each city. This is conducted by graphically analysing the types in order to detect the evolutionary characteristics of each period. In this examination, the analysis is centred on the ground floor of the housing unit, the house or villa. Therefore, it should be noted that all examples of the modern period and the example of the modern period of 


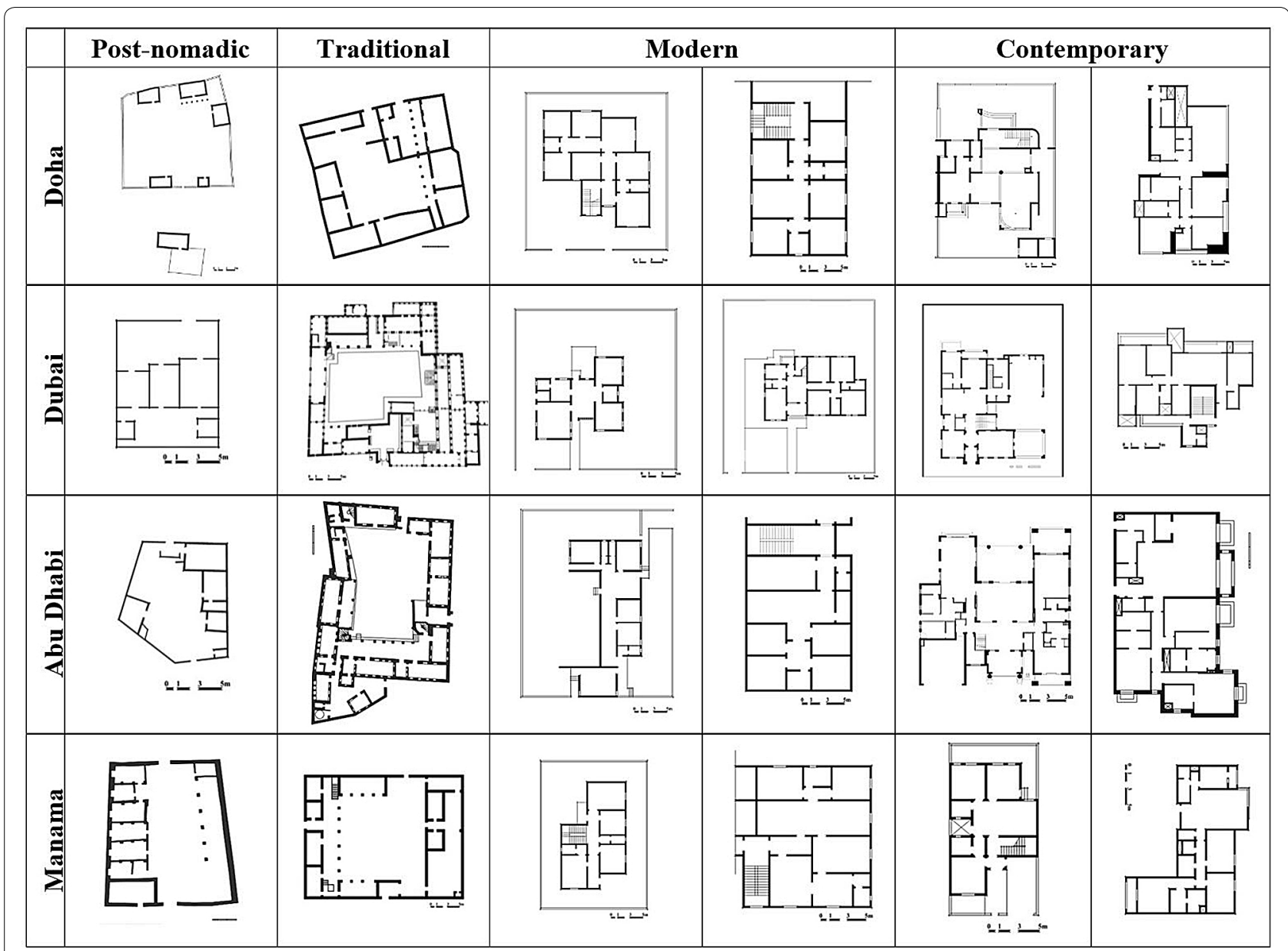

Fig. 1 The various case studies of housing types in the four Gulf cities. Source Redeveloped by the authors

Manama do not include bedrooms in the analytical drawings since family bedrooms are located in the upper floor which is accessible by stairways that are demonstrated in the drawings.

\section{Theoretical underpinnings on housing typologies}

The main concern of typology as a realm of investigation is to address the conceptual basis by which buildings can be classified and categorised into types. Demiri (1983) notes that typology is about the formal and spatial characteristics of buildings, which are rooted in culture and history. Typology in this sense is regarded as the "classification of models" (Salama 2006). According to Petruccioli (2007), a type is the organic ensemble of the common characteristics of buildings in a defined culture over a specific period of time. Thus, typological process is conceived in the context of this discussion as a dynamic process that changes and develops according to evolutionary paradigms of a particular society and that cannot be restricted to one formal scheme.
Petruccioli (2007) points out that it is possible to establish an explanation of the common generic sources and characteristics of types. Typological process is defined as dynamic evolutionary paradigms of a certain type of buildings of a particular society, in order to provide a clear generative interpretation of form transformation (Leupen et al. 1997). It is important to note that writings on typology emphasize that it should not aim at architectural styles; it is rather a set of descriptive categories that define the spatial characteristics of buildings over time (Gulgonen and Laisney 1982).

Typology has been used either as a basis for analysing buildings and cities (analytical typology) or as a basis for designing buildings (generative typology) (Leupen et al. 1997). The birth of a type is conditioned by the fact that a series of buildings share an obvious functional and formal analogy among themselves (Petruccioli 1998 p. 11). This is considered as a typo-morphological approach of interpreting and classifying the spatial and morphological characteristics of buildings as stated by Petruccioli 
(1998). Furthermore, the different variations within the same category of a type require clear identification in order to fully understand and interpret the building types in different cities. However, another level of typological analysis, which classifies the buildings within the different categories on the basis of their differences also, needs to be performed. It should be noted that each of the emerging typologies would include in itself the generic type. In essence and in the content of this investigation, typological analysis permits the examination, classification, recognition and description of residential buildings across different historic eras and across similar or different contexts.

Housing itself is a spatial phenomenon that has been linked with the subjective perception of shelter, security, comfort and desire (Alexander 1985). The individual home is a comfortable environment that is associated with intimate and relaxing behaviour shaped in specific size and type of spaces to enhance the spatial and social interaction (Chandhoke 2003). The residential unit has been recognised as a reciprocal interaction between the physical space, social life and interests of the householders, which have been rooted in peace, faith and purity (Philips 2008).

Alexander (1985) identifies two aspects as a base of a successful housing typology; how its uniqueness is expressed and how it is an appropriate social place connecting the family with other people and the society at large. Throughout history, housing typologies have been examined with respect to aspects of stronghold territory, in which certain measures of safety and protection have continuously been applied. This specific spatial organisation has limited the number of people who can easily enter private dwellings, which are restricted realms, requiring strangers to seek a permission to cross the private boundary (Bower 1980). In addition, Douglas (1991) adds that the spatial configuration of someone's habitat is not only what is located within the private physical boundaries, but also how people express their sense of belonging to the domain beyond the territory's border. The immediate outdoor areas of a dwelling are considered a vital and active part of the private living area (Abdelmonem 2015). Therefore, the traditional dwellers look at the adjacent public space as an extension of their private spaces.

The preceding theoretical tenets offer important insights toward understanding the evolutionary process of housing transformation within Gulf cities. In this respect, the paper examines the evolution and transformation of housing typologies from the perspective of the individual's experience and perception into a meaningful production of space. It discusses the production of residential models throughout the different periods as a set of activities shaping their spatial organisation.

\section{The four periods of settlement development in the Gulf}

The review of historical events in the region (Fig. 2), which had a significant impact on new social as well as economic realities, enables an understanding of various historic eras that can be classified into four periods as follows:

- The Post-Nomadic Period (until 1763)

- The Traditional Period (1763-1945)

- The Modern Period (1945-1990)

- The Contemporary Period (since 1990)

\section{The Post-Nomadic Period (until 1763)}

Before the British colonial influence commenced during the nineteenth century, the Gulf region was the home of Bedouin tribes and a very few oasis settlements. The traditional Bedouin economy was based on raising livestock, which is determined by the supply of water and the availability of grazing land (Ibn Khaldun 2004). The gradual exploration of underground oases permitted first date plantations and limited agriculture which the rich fishing grounds enabled a further supply chain of small settlements. The first oases settlements were thus the direct result of Bedouin culture and the gradual adjustment to agricultural lifestyles. Due to the limited water supply of each oasis a parallel and symbiotic coexistence of Bedouin and settled tribes have emerged over centuries and in spite of growing interdependencies a history of conflicts and slow population growth are clear indicators of very challenging living conditions.

In spite of the important geopolitical location along historic trading routes, Portuguese, Persian and Ottoman colonial influences have remained rather limited on settlements along the Gulf coast due to the harsh climatic conditions. The tribal structure combined major top-down decision-making, such as the distribution of land to the various clans, as well as self-organization and responsibility regarding the development and use of land (Salama and Wiedmann 2013). The built environment was thus a direct result of the inner socio-political and cultural circumstances and in addition to first cubic dwellings made of clay, mud and coral stones, a large part of the population still resided in tents and so called barast $i$ huts, which were made of palm fronds.

\section{The Traditional Period (1763-1945)}

In 1763 the British Empire installed an official colonial subdivision in the Gulf region, known as "Persian Gulf Residency" due to increasing trading activities towards 
MA

DO

$\frac{\text { DO }}{\text { MA }} \quad 1978$

Do

DO

DU

1972

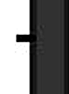

$1970 \mathrm{~s}$

AB

$\underline{\text { A }}$

1967

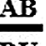

\section{DU}

DU

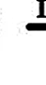

De

\section{DOA}

$\underline{A B}$
AB
MA

1931

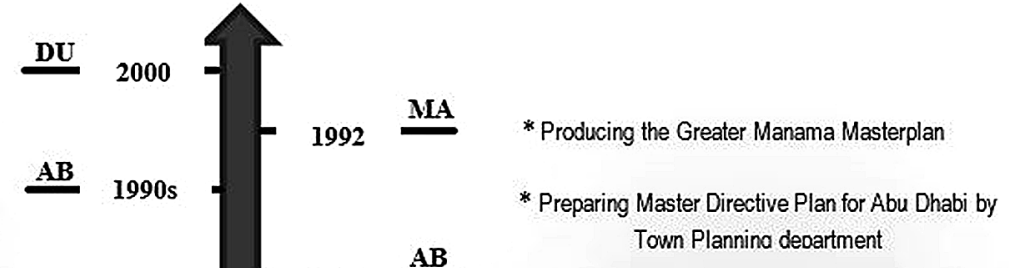 \\ \}$_{m+m}$}

Reviewing the existing urban areas and zoning in the city centre of Doha by William Pereira

* Establishing the National Housing Programmes

* Producing a series of planning studies known as the Concept Plan for North Districtor West Bay by William Pereira

* Forming the Ministry of Housing in Manama

*** Achieving independence after withdrawing

the Britain from the region and establishing the Ministry of Housing and Agriculture in Manama

* Applying detailed urban zoning of Abu Dhabi after assigning Makhlouf as a director of town planning department

$\underline{A B}$

* Establishing a programme of low-cost housing in Abu Dhabi

Do

* Establishing the first official housing policy in Doha

* Applying a holistic strategic urban plan to the city of Abu Dhabi by three Western firms

* Improving the infrastructure of the whole city of Doha and regenerating Abdulla bin Thani Street

* Implementing the public housing projects of Isa Town and Hamala Village

* Founding the Modern Dubai by Sheikh Rashid Al Maktoum

DU * Starting to export oil and establishing the local municipality in Dubai

DO * Starting to export oil and importing for first time cement and modern materials in Doha

Do

* Discovering the Oil in Qatar

MA

* Establishing the municipality of Manama
* Updating the urban development regulations to be more compatible with the city growth

* Establishing Sheikh Zayed Housing Programme under the federal law 10 Sir Jon Harris

* Applying reinforced concrete for the first time in Bar Deira

* Shaping the Makhatira administration under the Baladiyya model in Manama

* Expanding the city of Doha by constructing traditional and concrete buildings along Al-Kharaba Street

* Discovering the offshore oil in Abu Dhabi and a

year later onshore reserves was found
\[ \text { * Discovering the Oil in Bahrain } \]

year later onshore reserves was found
\[ \text { * Discovering the Oil in Bahrain } \]

\section{* Developing and expanding the housing project of Hamad Town according to 1981 decree \\ * Refining a three-classification system of houses in Doha followed by the new housina policy \\ * Reclaiming 630 hectares in the north of Doha \\ * Developing and expanding the housing project of lsa Town according to 1976 decree \\ * Designing the first masterplan of Doha for 1990 by Llewelyn Davis under the new town planning authority \\ * Establishing the Physical Planning Unit under
the Ministry of Housing and Agriculture
* Designing and implementing the low-cost
housing by the municipality of Dubai
* Developing a general layout of the city of Abu Dhabi
by Architect Takahashi
* Producing the second development plan by
TCDA in Doha
* Starting to export Abu Dhabi's onshore oil
* Founding the municipality of Abu Dhabi
* Providing the regulation of building codes to preserve
the evolution of modern construction by the municipality
* Creating the first urban planning project of Dubai by \\ * Establishing the Physical Planning Unit under
the Ministry of Housing and Agriculture
* Designing and implementing the low-cost
housing by the municipality of Dubai
* Developing a general layout of the city of Abu Dhabi
by Architect Takahashi
* Producing the second development plan by
TCDA in Doha
* Starting to export Abu Dhabi's onshore oil
* Founding the municipality of Abu Dhabi
* Providing the regulation of building codes to preserve
the evolution of modern construction by the municipality
* Creating the first urban planning project of Dubai by \\ * Establishing the Physical Planning Unit under
the Ministry of Housing and Agriculture
* Designing and implementing the low-cost
housing by the municipality of Dubai
* Developing a general layout of the city of Abu Dhabi
by Architect Takahashi
* Producing the second development plan by
TCDA in Doha
* Starting to export Abu Dhabi's onshore oil
* Founding the municipality of Abu Dhabi
* Providing the regulation of building codes to preserve
the evolution of modern construction by the municipality
* Creating the first urban planning project of Dubai by \\ * Establishing the Physical Planning Unit under
the Ministry of Housing and Agriculture
* Designing and implementing the low-cost
housing by the municipality of Dubai
* Developing a general layout of the city of Abu Dhabi
by Architect Takahashi
* Producing the second development plan by
TCDA in Doha
* Starting to export Abu Dhabi's onshore oil
* Founding the municipality of Abu Dhabi
* Providing the regulation of building codes to preserve
the evolution of modern construction by the municipality
* Creating the first urban planning project of Dubai by \\ * Establishing the Physical Planning Unit under
the Ministry of Housing and Agriculture
* Designing and implementing the low-cost
housing by the municipality of Dubai
* Developing a general layout of the city of Abu Dhabi
by Architect Takahashi
* Producing the second development plan by
TCDA in Doha
* Starting to export Abu Dhabi's onshore oil
* Founding the municipality of Abu Dhabi
* Providing the regulation of building codes to preserve
the evolution of modern construction by the municipality
* Creating the first urban planning project of Dubai by \\ * Establishing the Physical Planning Unit under
the Ministry of Housing and Agriculture
* Designing and implementing the low-cost
housing by the municipality of Dubai
* Developing a general layout of the city of Abu Dhabi
by Architect Takahashi
* Producing the second development plan by
TCDA in Doha
* Starting to export Abu Dhabi's onshore oil
* Founding the municipality of Abu Dhabi
* Providing the regulation of building codes to preserve
the evolution of modern construction by the municipality
* Creating the first urban planning project of Dubai by \\ * Establishing the Physical Planning Unit under
the Ministry of Housing and Agriculture
* Designing and implementing the low-cost
housing by the municipality of Dubai
* Developing a general layout of the city of Abu Dhabi
by Architect Takahashi
* Producing the second development plan by
TCDA in Doha
* Starting to export Abu Dhabi's onshore oil
* Founding the municipality of Abu Dhabi
* Providing the regulation of building codes to preserve
the evolution of modern construction by the municipality
* Creating the first urban planning project of Dubai by \\ * Establishing the Physical Planning Unit under
the Ministry of Housing and Agriculture
* Designing and implementing the low-cost
housing by the municipality of Dubai
* Developing a general layout of the city of Abu Dhabi
by Architect Takahashi
* Producing the second development plan by
TCDA in Doha
* Starting to export Abu Dhabi's onshore oil
* Founding the municipality of Abu Dhabi
* Providing the regulation of building codes to preserve
the evolution of modern construction by the municipality
* Creating the first urban planning project of Dubai by \\ * Establishing the Physical Planning Unit under
the Ministry of Housing and Agriculture
* Designing and implementing the low-cost
housing by the municipality of Dubai
* Developing a general layout of the city of Abu Dhabi
by Architect Takahashi
* Producing the second development plan by
TCDA in Doha
* Starting to export Abu Dhabi's onshore oil
* Founding the municipality of Abu Dhabi
* Providing the regulation of building codes to preserve
the evolution of modern construction by the municipality
* Creating the first urban planning project of Dubai by \\ * Establishing the Physical Planning Unit under
the Ministry of Housing and Agriculture
* Designing and implementing the low-cost
housing by the municipality of Dubai
* Developing a general layout of the city of Abu Dhabi
by Architect Takahashi
* Producing the second development plan by
TCDA in Doha
* Starting to export Abu Dhabi's onshore oil
* Founding the municipality of Abu Dhabi
* Providing the regulation of building codes to preserve
the evolution of modern construction by the municipality
* Creating the first urban planning project of Dubai by \\ * Establishing the Physical Planning Unit under
the Ministry of Housing and Agriculture
* Designing and implementing the low-cost
housing by the municipality of Dubai
* Developing a general layout of the city of Abu Dhabi
by Architect Takahashi
* Producing the second development plan by
TCDA in Doha
* Starting to export Abu Dhabi's onshore oil
* Founding the municipality of Abu Dhabi
* Providing the regulation of building codes to preserve
the evolution of modern construction by the municipality
* Creating the first urban planning project of Dubai by \\ * Establishing the Physical Planning Unit under
the Ministry of Housing and Agriculture
* Designing and implementing the low-cost
housing by the municipality of Dubai
* Developing a general layout of the city of Abu Dhabi
by Architect Takahashi
* Producing the second development plan by
TCDA in Doha
* Starting to export Abu Dhabi's onshore oil
* Founding the municipality of Abu Dhabi
* Providing the regulation of building codes to preserve
the evolution of modern construction by the municipality
* Creating the first urban planning project of Dubai by \\ * Establishing the Physical Planning Unit under
the Ministry of Housing and Agriculture
* Designing and implementing the low-cost
housing by the municipality of Dubai
* Developing a general layout of the city of Abu Dhabi
by Architect Takahashi
* Producing the second development plan by
TCDA in Doha
* Starting to export Abu Dhabi's onshore oil
* Founding the municipality of Abu Dhabi
* Providing the regulation of building codes to preserve
the evolution of modern construction by the municipality
* Creating the first urban planning project of Dubai by}
DO $=$ Doha
$\mathbf{D U}=$ Dubai
$\mathbf{A B}=$ Abu Dhabi
MA = Manama

Fig. 2 The key events within local urban governance impacting housing development in the four selected Gulf cities. Source Authors 
India (Peterson 2008). The interaction between the various tribes and the British East India Company have mainly focused on preventing emerging piracy and to establish ports for repairing ships as well as for trade, which was limited to pearls. As a result, the commencing international pearl trade became the most important factor in settlement growth, which was accelerated by the move of inland tribes as well as Indian and Persian merchant families in addition to East-African slaves, engaged as pearl divers (Al-Maani and Alsharari 2014).

The population of most settlements remained below 50,000 inhabitants. However, the import of new construction techniques, such as the Persian wind towers, and the large income differences between the various social classes in addition to the segregation of the various ethnic groups led to an increasing differentiation of building typologies, from large courtyard complexes of wealthy clan leaders to palm frond huts of pearl divers. The ports and first large-scale markets led to defined public centres, where all social groups interacted. The various neighbourhoods were developed in proximity to these commercial centres. While an official urban administration was not yet established, emerging conflicts between neighbours were usually solved by official gatherings of tribal leaders (Hakim 2007).

\section{The Modern Period (1945-1990)}

The first phase of modern urbanization was dominated by the development of first infrastructural networks, including water, electricity and sewage (Fuccaro 2009). First roads were built to connect ports and newly established airports with oil fields and first settlements for guest workers, engaged in the oil production and infrastructural development. The rapid wealth increase led to the introduction of social welfare mechanisms and the focus on enhancing the living conditions of the local populations in order to avoid political disputes of tribal leaders, supported by the British protectorate (Abdulla 2010). The most important development during this period was the establishment of modern housing connected to modern infrastructure.

Due to the rather narrow distances between buildings and small plot sizes in traditional settlement areas, the local populations moved to newly built suburban neighbourhoods, which followed Western construction methods and standards. The import of a modern construction industry was entirely detached from the local population and first housing typologies were thus mainly influenced by the common housing design and standards of more developed countries in the Middle East, such as Egypt and the Levant. This was an outcome of the vast immigration from the region and South-Asia and led to these rapidly growing settlements. While the first planning units were focused on developing an infrastructural backbone and first building standards (Al-Sammani 2011), the national independence of most Gulf countries between 1961 and 1971 led to the foundation of first public administration jurisdictions and the establishment of capital cities (Wiedmann 2012).

During the following decades the provision of sufficient housing for the local population has remained one of the most important public sector responsibilities. In 1976 a decree was issued in Bahrain to establish the Ministry of Housing in order to provide social housing for citizens with limited income. This gave a boost to expand largescale housing projects in Isa Town and Hamad Town in 1978 and 1984 (Wiedmann 2012; Al-Nabi 2012). During the 1980s, the National Housing Programmes were established in the UAE, providing free funds of Dhs 200,000 (Approx \$US 60,000) with serviced land (Al-Mansoori 1997). In 1984, Qatar's Ministry of Municipal Affairs and Agriculture (MMAA) defined a three-level classification system of houses: free houses, public houses and senior staff houses. As part of this system a new policy that allowed the involvement of users in the design of their own houses or villas (a two-story self-contained house) was introduced, which was based on a catalogue developed by the municipality that included a few alternative designs (Nagy 2000).

\section{The Contemporary Period (since 1990)}

The end of the Cold War and the rising global trade instigated a new role of the Gulf region, as main trading and transit hub due to its geopolitical location (Khalaf 2006). In addition to the enhanced impact of globalisation, rulers launched new national development visions in order to initiate economic diversification (Salama and Wiedmann 2013). After the introduction of free economic zones and tourism the liberalisation of local real-estate markets led to an unprecedented construction boom at the beginning of the new millennium, particularly in Dubai followed by all major Gulf cities (Wiedmann et al. 2012). Subsequently, the housing market witnessed a rapid diversification to accommodate the interests of investors and the emerging government-private developers. Due to rising land prices and limited land with access to infrastructural grids the construction boom introduced luxurious apartments as housing alternative to suburban villas for upper income groups, including local populations.

Despite the rapid expansion of the private sector rulers have remained the main driving force of any development due to their decision-making capacity with respect to direct investments of oil and gas revenues in infrastructure and key projects as well as the fact that most development land has still remained under their control, 
and in particular, the newly reclaimed land on waterfronts. In addition, the public sector has remained in charge of supplying housing, such as the Sheikh Zayed Housing Programme in Abu Dhabi during the 1990s. Housing development during this period is defined by major mega projects, which were often planned as citieswithin-cities. While most developments have been initiated along coastal areas, urban sprawl has continued in the form of expanding suburban residential districts made of both large gated compounds for expatriate professionals as well as segregated neighbourhoods for the local population. A new phenomenon in recent years has been the initiation of projects within downtown areas in order to attract the younger generation of locals to relocate from suburban to inner-city districts. One prominent example in this regard is the Msheireb development in Doha (Wiedmann and Salama 2013).

The preceding analysis of the four historic eras suggests that the foundation periods of the selected Gulf cities share the same historical background, which generated comparable schemes in urban, economic and political developments. While this goes along earlier analyses on the topic (Qutub 1985; Khalaf 2006; Fox et al. 2006), the analysis in the context of the preceding discussion insinuates that economic, social and political factors have played a key role in shaping housing developments and emerging typological patterns. Yet, since the discovery of oil in the region, a massive urban transformation program was initiated and different strategies were introduced in order to establish new spatial patterns accommodating both local and international lifestyles. In the four Gulf cities international standards for urban planning, infrastructure and zoning were adopted in order to establish functioning regional and global hubs. Figure 2 outlines the key events within urban governance chronologically including the establishment of new government bodies, local authorities, master plans and guidance policies.

\section{Mapping housing typologies to the four historical periods in four cities}

The analysis of the housing evolution within the four Gulf cities conveys that not only the social values that have defined the housing typology or the spatial organization of the house, but also the economic development and political legitimacy. The initial post-nomadic model is rooted in erecting fences around tents in order to define individual plots for each family. Simple cubic buildings made of basic local materials such as palm-fronds, mud, and coral stones gradually replaced first huts and tents. Each plot consisted of a walled enclosure open spaces filled with one story room or several rooms positioned along the plot's perimeter (Jaidah and Bourennane 2010).
This basic shelter encompasses only main spaces that were essential for families, including private living areas, guest reception, cooking, storage and utility. Spaces were arranged within one plot surrounded by a wall to provide a family privacy and a clear territorial boundary and ownership (Fig. 3). The reception space was located within the plot ground and was directly accessible from the public domain in order to preserve the family privacy and to make a clear separation between the men's gathering and family's daily life. With the absence of the official governmental regulations, this model was strongly associated with socio-economic aspects, where residences reflect the general social status in terms of size, type and nature of spaces, as well as the quality of details.

The traditional model can be considered as an advancement of the post-nomadic model. The emerging pearl trade during the nineteenth century generated new new housing standards. The concomitant growth of the family or the accommodation of extended family members led to erecting more covered spaces within the same dwelling plot, and therefore, a central open space or a courtyard was shaped in similitude to other settlement throughout the Middle East. Most traditional houses were arranged around a central private courtyard where family activities took place. As the central primary open space, the courtyard became the heart of the traditional dwelling, where all the functions such as majlis (family or visitors sitting area), living spaces, bathroom and iwans were connected. Traditionally, the courtyard contained a fountain and a small garden or fruitful trees in order to provide shaded areas and help with the cooling (Hawker 2008). The majlis was often located near the entrance and used to receive men's visitors or conduct a business; it was often kept separated from the rest of the house. Occasionally, an intermediate yard may lead to an adjacent house, accommodating additional wives or an extended family (Fig. 4). The main concept behind designing the courtyard house was to generate an inward-looking plan with plain external walls, which were designed to discourage strangers from looking inside the house as well as to protect the house from the harsh climate of the region (Regette 2003; Edwards et al. 2006; Salama 2006).

In the context of discussing the traditional Gulf house it is important to refer to its most unique features. The wind tower was introduced to help soften the impact of the desert scorching heat while creating pleasant, better ventilated interior spaces. In addition, the roof terrace is an open space located in the house's upper floor and is accessible by staircase, which is flexible to be used for both family and guests. This upper level space was fully occupied in the evenings of the summer time. During the daytime it was a place for drying vegetables. In the late night time, the space is turned into a sleeping area 


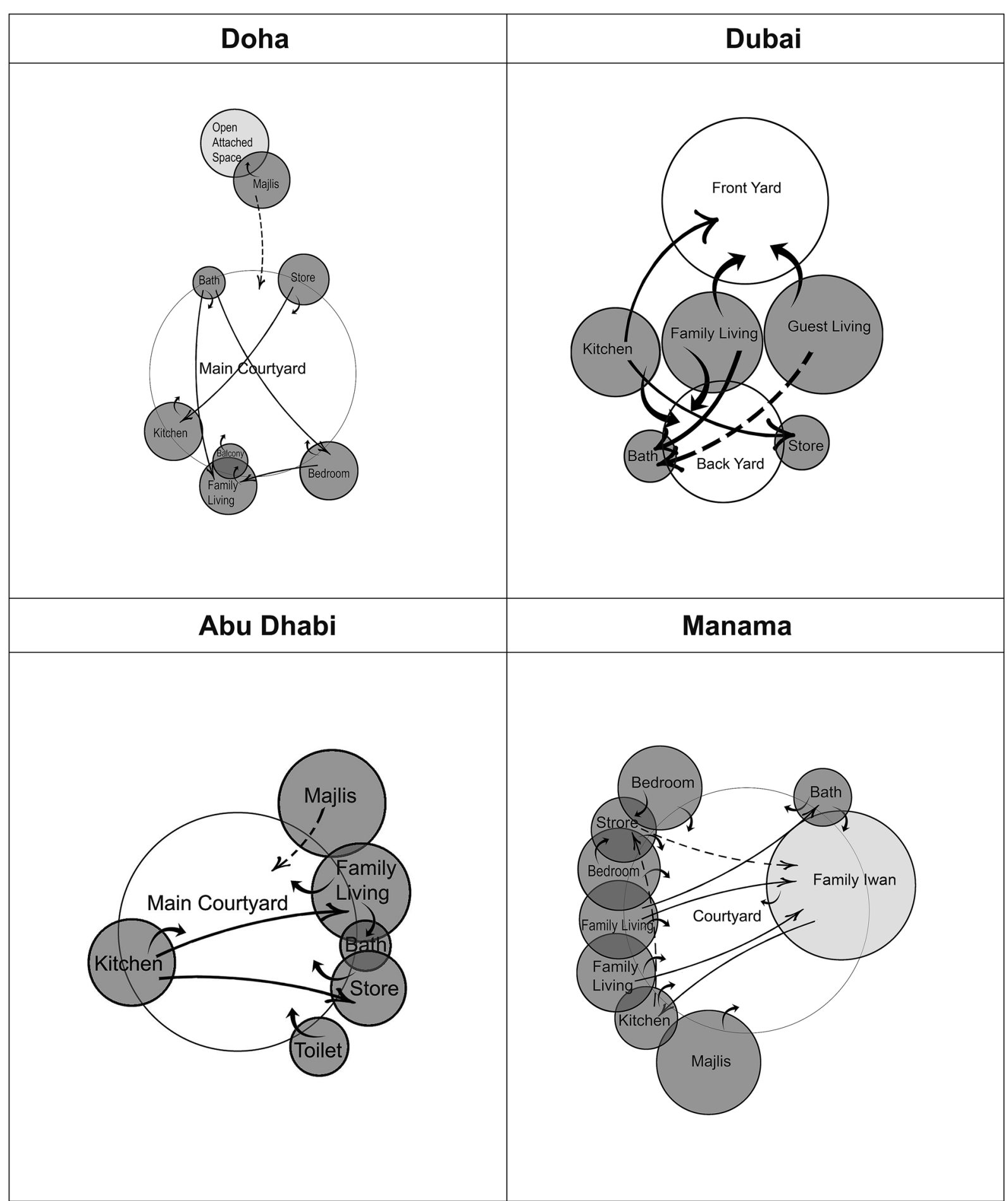

Fig. 3 The internal relationships of spaces within the post-nomadic housing typology in the four cases. Source Authors

as it was exposed to the pleasant breeze. It is important to note that the traditional houses in the Gulf region were not identical but they shared many features that included courtyard, majlis (men's reception), private area (bedrooms and maid suite), servicing area (kitchen, stores, staircase and wind tower) and roof terrace. The traditional house represents a spontaneous model that refers to a humble experience of local skills and the 


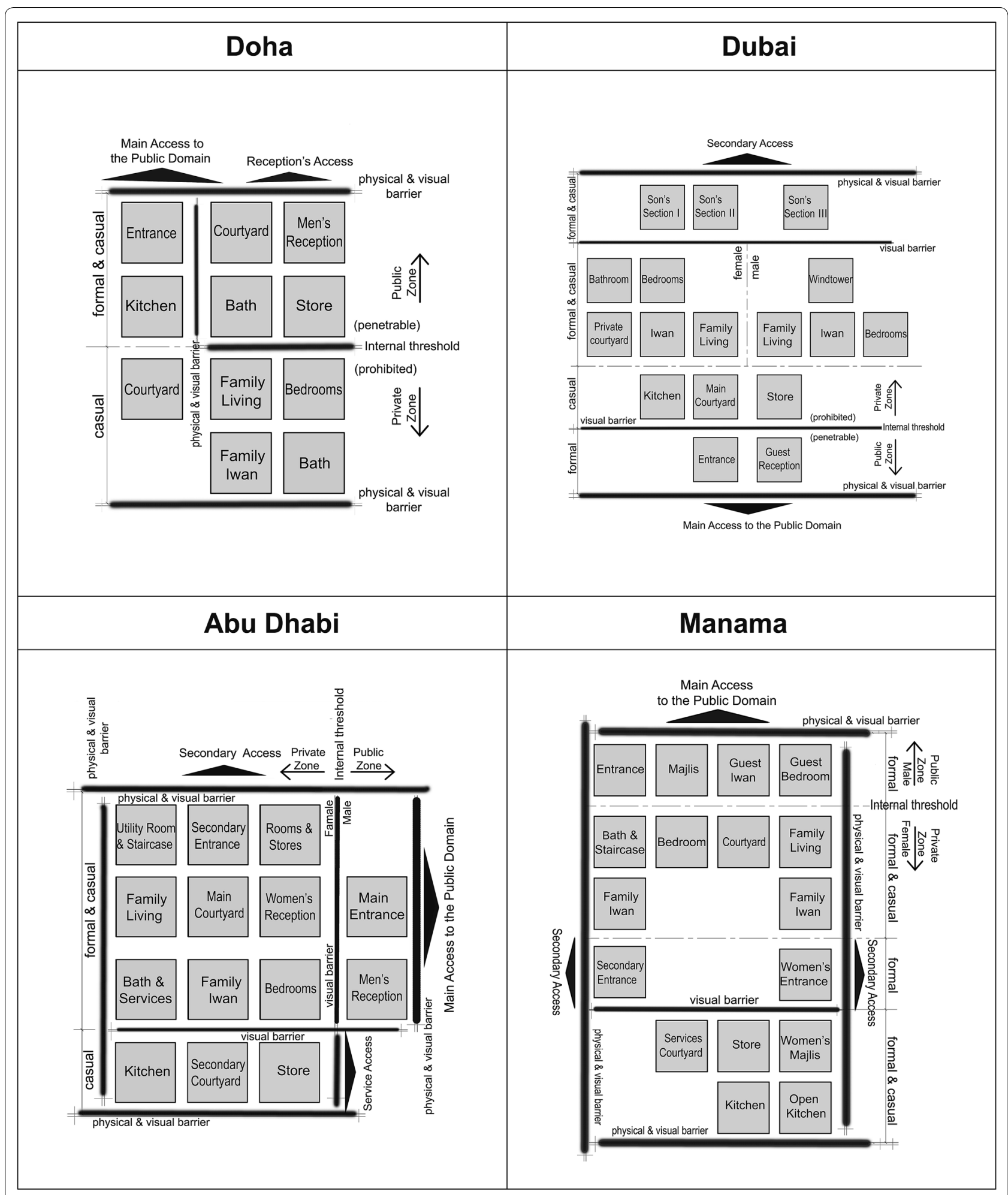

Fig. 4 The spatial organisation of the traditional housing typology in the four cities. Source Authors 
limitation of the available local construction materials. Nevertheless, it is widely acknowledged as a distinctive example of a housing development that perfectly confronts the harsh desert climate and responds adequately to the basic needs of its users.

The modern model followed a new strategy, reflecting the new prosperity that has resulted in an influx of foreign engineers and architects as well as in the use of new construction techniques and materials. Two types of residential units were introduced as modern models, a villa and an apartment with the aim of improving the standards of Bedouin life that was dominant in the entire Gulf region. The villa was introduced first by the government as standard housing typology for locals and followed the traditional expectation of individual land ownership. In contrast to the traditional typology of courtyard houses, the internal spaces of a modern villa are oriented outward towards the surrounding yards or outdoor spaces. Most of the villa models are one or two storey high and are placed in the centre of the plot surrounded by open spaces, car parks and gardens (Fig. 5). A tall wall was added to protect the family privacy and to define the private space. The arrangement of interior spaces preserved the traditional spatial organisation to some extent. The majlis rooms were still located in close proximity to entrance spaces in order to enable a separation between private family life and visitors.

Stairways and living areas were used as central spaces connecting all rooms replacing the function of courtyards. The living room is signified as the archetype of privacy and intimacy and became a symbolic space for family gathering. This space is mostly open and visible from the surrounding daily family activities and was commonly supplied by flexible furniture. The modern interior layout combines basic spaces that respond to family needs, creating minimum space for circulation. In many cases two functions were accommodated by one singular space such as: living and dining, or kitchen and dining, or guest reception and guest dining. In the ground floor a guest bedroom was part of the spatial organization, whereas the main sleeping rooms are located in the upper floor. In the case of one storey, the central living space at the ground floor level is attached with all other spaces. Conversely, in the case of two storeys or more, this living space is linked horizontally with all daily life spaces and vertically with the most private spaces such as bedrooms by the stairway (Fig. 5). The modern flat was almost a small compact model of the modern villa. It had a clear separation between the guest reception space and the family living areas.

The contemporary models have evolved out of the modem model. However, all contemporary models including villas, apartments and townhouses, have mainly followed international trends, wherein the traditional socio-cultural context as well as the desert climate have taken a back seat as design imperatives. The recent construction boom has mainly been guided by speculation-driven mechanisms leading to imported and hardly adjusted housing typologies, such as residential high-rises, apartment blocks and townhouses within large compounds. In order to reduce costs and enhance the number of housing units, open plan living areas were introduced as multi-functional spaces integrating reception, family living, dining and cooking. The high demand for privacy was only accommodated in the form of large bedrooms, which however led to proportionally limited spaces for shared use. Today, it can be argued that the recent surge in construction activities has created two new realities for the local population: Firstly, the high land prices and construction costs leading to a shrinking number of locals, who can embark on an effort to build their modern villas in accessible locations. Secondly, large supplies of new housing units in form of mega projects (large-scale compounds, or gated communities) manifest a clear break from previous lifestyles and traditions. However, the general interior layout of contemporary villa is considered to be an advanced model of the modern villa that mixes between traditional features and international standards and styles. Most of the contemporary villas maintain the guest reception slightly separated from the rest of the living spaces, but still easily accessible visually and spatially. On the other hand, a hierarchy between the bedrooms and family living space is achieved, which keeps the most private spaces integrated with the living spaces while preserving their privacy simultaneously (Fig. 6).

The design of the contemporary apartment on the other hand, focuses essentially on how to accommodate different users who have multi-ethnic backgrounds, using cutting-edge technology. This model is a built manifesto that is based on a new language and architectural style, which reveals the immense possibilities of transformation and with complete denial of the harsh environmental conditions. The result is a new contemporary typology where freedom of movement inside the housing unit took place without sufficient consideration privacy requirements. This entails that the original features with respect to the separation between the interior private spaces and the guest reception area are conflicting. The contemporary model brings up the family to a multifunctional use of the spaces, without conventional limits. For this reason the residential unit is provided with a large living room space for multiple functions.

In essence, housing evolution in the Gulf cities can be categorised, following Alexander (2012) classification, into two observable systems. The first system occurred 


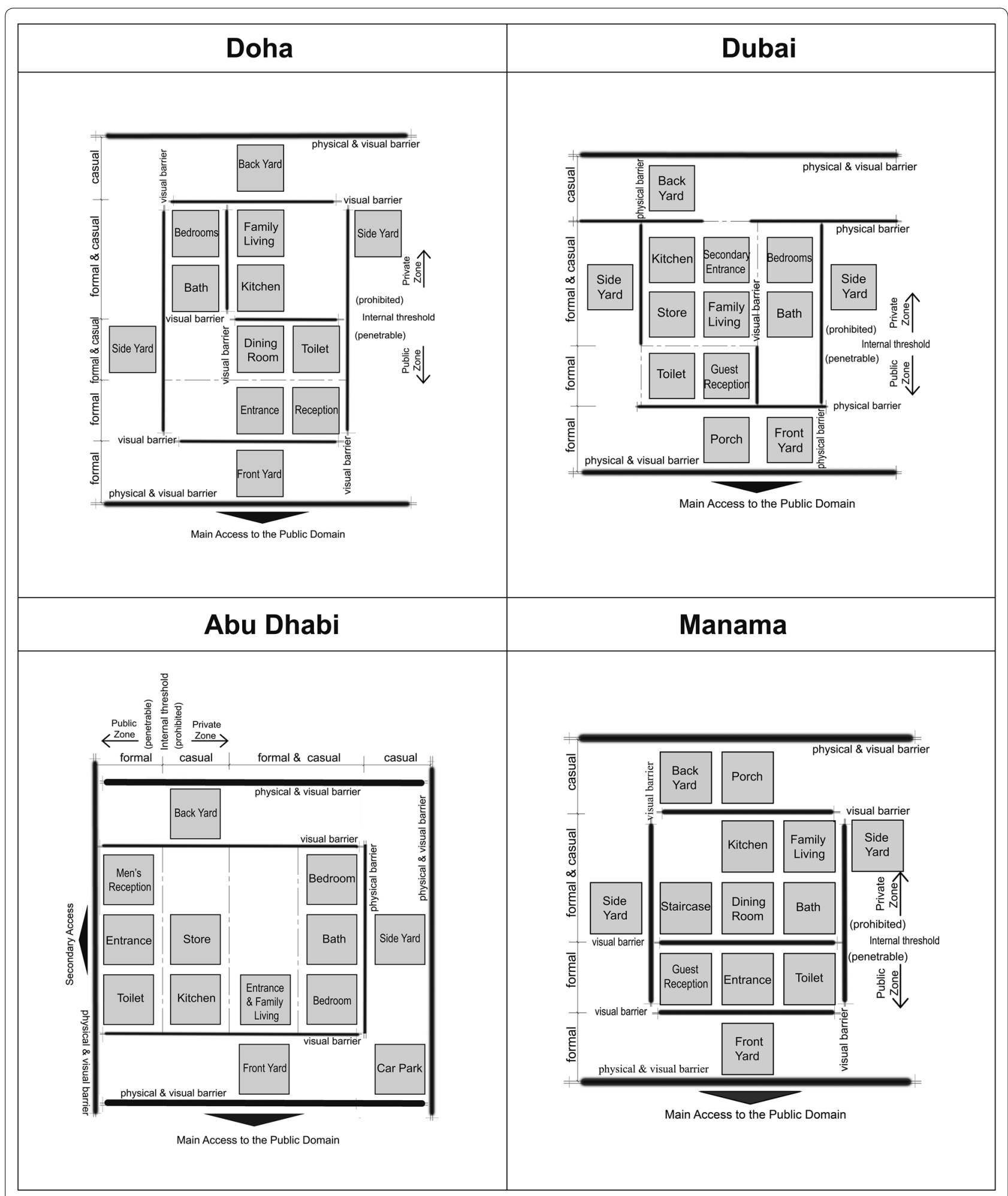

Fig. 5 The spatial organisation of the modern housing typology in the four cities. Source Authors 


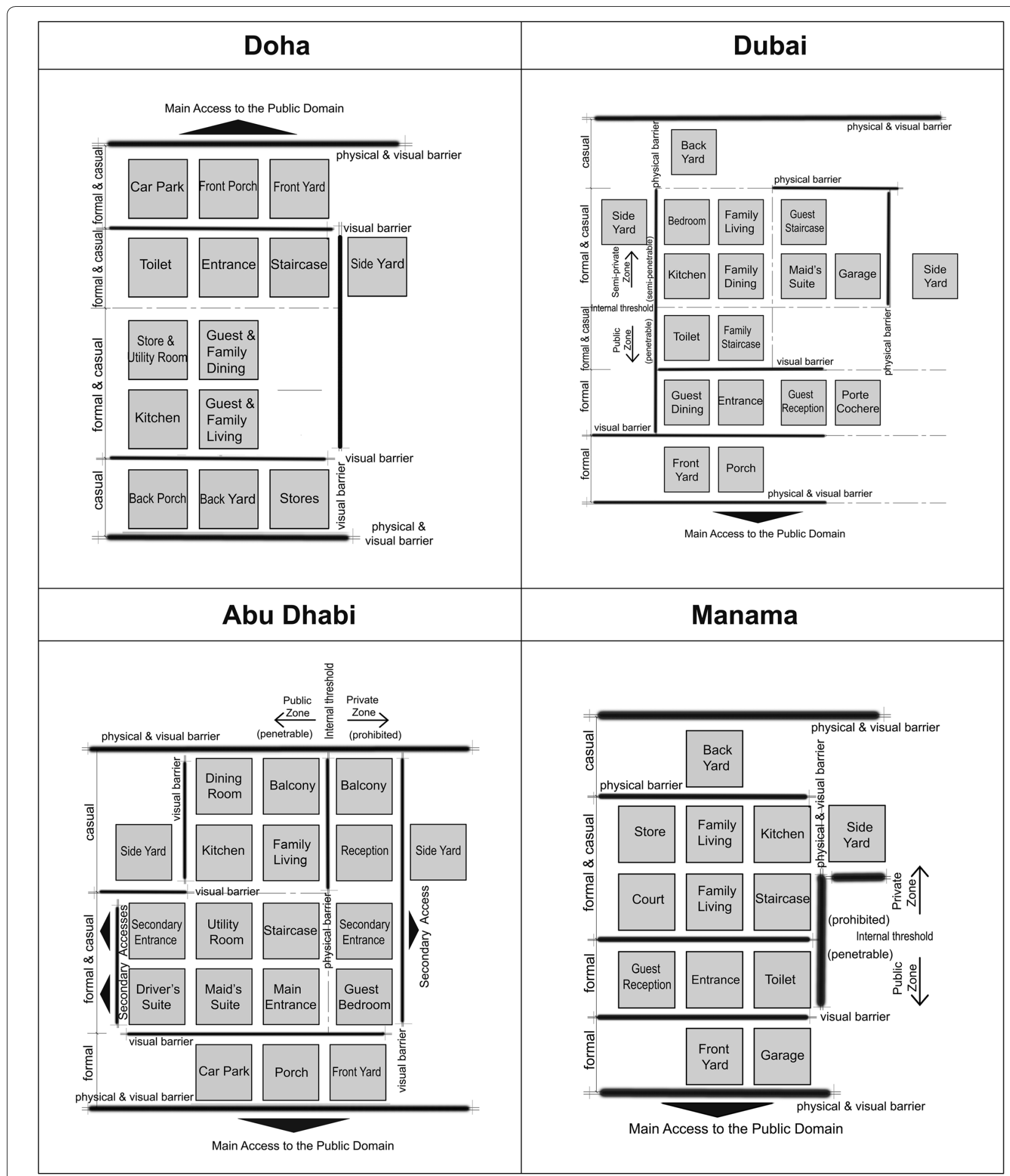

Fig. 6 The spatial organisation of the contemporary housing typology in the four cities. Source Authors

during the pre-oil period followed by the creation and production of housing rooted in an organic process, governed by human needs, wants and judgments, which originated from the essential wholeness of situations, conditions and surroundings. The second system took place during the period of modern urbanisation, which reflected the housing production as a mechanical process and is based on governmental regulations, procedures, 
categories and efficiency. All machinery of housing strategies and implementation in this period was designed to make societies run smoothly. However, the post-oil housing production process has rarely been context-sensitive while following market logic. Thus, traditional values and lifestyles were accommodated in the form of added walls and separate doors rather than as driving forces defining the inner configuration and the spatial organization of houses.

\section{Conclusion}

The evaluated post-nomadic and traditional models in all four Gulf cities exhibited a high level of synergies between socio-cultural practices and spatial configuration. Thus, the first two phases of the housing evolution represent a collective development reflecting both the cultural needs as well as the various environmental constraints. The study furthermore unveils that the modern and contemporary phases reflect international housing standards in which the spatial configuration of housing typologies have been following global economic forces. Due to imported policies, construction materials and techniques the originality of housing in the Gulf region has been disoriented. While detached dwellings could be still tailored to certain cultural needs, such as gender separation and the needs for privacy, the recent surge in housing production has created new built realities for young generations of locals to adjust to new housing typologies with limited sizes and spatial configurations based on international lifestyle models.

The contemporary urban condition with respect to housing production reveals rising tensions between the general housing expectations of local populations and the new realities rooted in liberalized housing markets and continuously increasing land prices. Various efforts are currently carried out to introduce new housing standards for local populations by integrating cultural needs in the case of comparatively small residential units. In the Kingdom of Bahrain, a townhouse project has been launched as part of the Diyar Al Muharraq project integrating separate majlis rooms and small courtyards. The supply of daylight via small courtyards adds to a more introverted layout and thus private living spaces, while the majlis is located at the entrance separating male guests from family spaces. In the case of the Msheireb project in Doha the aim is to bring the local community from the city's peripheries to the urban core. Attracting the local population to the urban core is achieved by utilizing traditional design elements in an exclusive housing district while at the same time creating a spatial distance from migrant communities and their lifestyles.

In all contemporary examples of re-establishing housing as a reflection of local tradition and culture, the courtyard, private family space and the separate majlis in proximity to main entrances play the most important roles. These design elements however demand larger plot sizes in order to function and are rooted in a rarely discussed reality. As presented in this paper the housing evolution in the Gulf region began with simple huts, which were transformed into cubic buildings on small plots. The built density was generally high in order to enable shaded walls and a short walking distance to few water sources. The pearl trade and the emerging wealth of certain families enabled larger residential complexes and the formation of many buildings around courtyards. While prominent examples of these courtyard buildings can still be visited in Muharraq and Dubai, the typical cubic buildings, in which most of the population resided before the oil production began, were completely replaced and never restored (Fig. 7). The oil wealth and social welfare mechanisms led to the generic approach of rulers to support a high living standard and thus the size of modern dwellings is conceived to be comparable to the size of large courtyard houses. This instant and extensive upgrade from little cubic buildings made of mud and palm fronds to modern villas during the 1960s and 1970s has enabled all locals to embrace a lifestyle on plot sizes, which were previously limited to rulers and wealthy merchants.

Today, urban governance has to mediate between the general housing expectations and the new reality of housing as main investment opportunity leading to rising land prices in all cities. In order to reduce urban sprawl locals will need to adapt to the limited sizes of their future residences. The desired move of locals from far-distant suburban districts on cities peripheries can however only succeed, when residential projects integrate key important qualities: A generally introverted layout based on a central core from where all rooms can be accessed, various layers of family privacy and a certain distance to migrant communities. The major potential in this regard can be found in exclusive residential projects along the coast, including high-rises, which however face two main obstacles (Fig. 7). The first is the general security concerns regarding fire and the second is the lack of conviction to invest in apartments as long-term residences. Among socio-cultural factors the general hesitation to move to apartments is rooted in doubts regarding the construction standards, future maintenance costs and unpredictable changes within the immediate surroundings. If these hindering factors can be removed, the current trend of young local families relocating to recent projects can mark another step within the housing evolution in Gulf cities; From densely built vernacular settlements to sprawling suburban realms and finally 

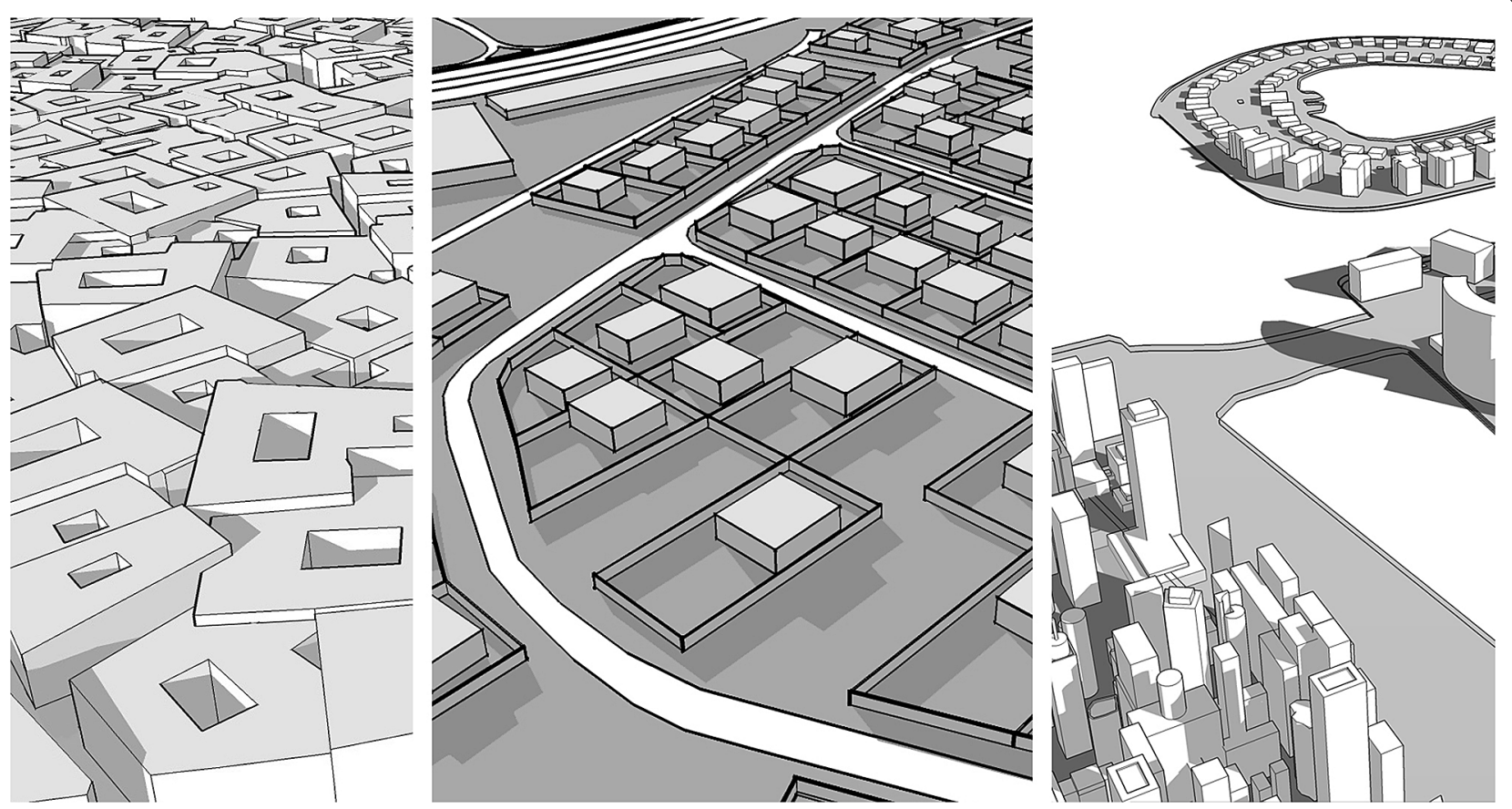

Fig. 7 A demonstration of housing transformation in the Gulf. Source Authors

to dense clusters of residential towers and blocks along waterfronts (Fig. 7).

The transformation of housing typologies from very limited spaces to excessive spaces and back to reduced spaces in modern urban environments is furthermore a clear reflection of how oil revenues were first invested in supplying local populations with high living standards, while today oil revenues are used to promote the development of new service economies. These new service economies however rely on fast urban growth mechanisms, which have led to the rapid end of extensive public housing supply in most Gulf cities as in previous decades.

\section{Authors' contributions}

AR carried out the review of house types, conducted the typological analysis and contributed to the mapping of housing typologies to various historical periods. AS conceived of the study, participated in developing the methodology, and in drafting, reviewing, and editing the manuscript. FW developed the historical background and participated in the development of the descriptive analyses of house types and linking them to urban dynamics as portrayed in the conclusion. HI participated in the development of the methodology, in the identification of historical events, and to gathering information about house types. All authors read and approved the final manuscript.

\section{Author details}

${ }^{1}$ Department of Architecture, University of Strathclyde, Level 3, James Weir Building, 75 Montrose Street, Glasgow G1 1XJ, UK. ${ }^{2}$ Department of Architecture and Urban Planning, Qatar University, Doha, Qatar.

\section{Acknowledgements}

This paper is developed as part of a comprehensive funded research project of the National Priorities Research Program, QNRF-Qatar National Research Fund (NPRP 7-960-5-135), entitled: Investigating Housing Typologies in Multicultural
Societies of the Gulf Region, a collaboration between University of Strathclyde, Glasgow and Qatar University, Doha. The authors acknowledge the resources offered through the leadership fund of the Department of Architecture at the University of Strathclyde toward developing this work.

\section{Competing interests}

The authors declare that they have no competing interests.

Received: 11 August 2016 Accepted: 15 September 2016

Published online: 22 September 2016

\section{References}

Abdelmonem MG (2015) The architecture of home in Cairo: socio-spatial practice of the Hawari's everyday life. Routledge, London

Abdulla A (2010) Contemporary socio-political issues of the Arab Gulf moment. LSE-London School of Economics, London

Alexander C (1985) The production of houses. Oxford University Press, New York

Alexander C (2012) Battle for the life and beauty of the Earth: a struggle between two world-systems. Oxford University Press, New York

Al-Maani AA, Alsharari S (2014) Pearl trade in the Persian Gulf during the 19th Century. Asian Cultur Hist 6(1):43-52

Al-Mansoori MA (1997) Government low-cost housing provision in the United Arab Emirates: the example of the Federal Government low-cost housing programme. Dissertation, University of Newcastle upon Tyne, Newcastle

Al-Nabi MN (2012) The history of land use and development in Bahrain. Information Affairs Authority, Manama

Al-Sammani AM (2011) The sustainable development of local housing units in UAE. Dissertation, the British University in Dubai, Dubai

Bower SN (1980) Territory in urban settings. In: Altman I, Ropoport A, Wohlwill JF (eds) Environment and culture. Spring Science, New York

Chandhoke N (2003) Private, public and search for home. In: Mahajan G, Reifeld $\mathrm{H}$ (eds) The public and the private: issues of democratic citizenship. Sage Publications, New Dehli 
Demiri D (1983) The notion of type in architectural thought. Edinb Archit Res 10:117-137

Douglas M (1991) The idea of home: a kind of a space. Soc Res 58(1):287-307

Duany A, Plaer-Zyberk E, Speck J (2010) Suburban nation: the rise of sprawl and the decline of the American dream. North Point Print, Waltham

Edwards B, Sibley M, Hakmi M, Land P (2006) Courtyard housing: past, present and future. Taylor \& Francis Group, New York

Fox J, Sabbah N, Al-Mutawa M (eds) (2006) Globalisation and the Gulf. Routledge, London

Fuccaro N (2009) Histories of city and state in the Persian Gulf: Manama since 1800. Cambridge University Press, Cambridge

Gulgonen A, Laisney F (1982) Contextual approaches to typology at the Ecoles des Beaux-Arts. J Archit Educ 35(2):26-29

Hakim B (2007) Revitalizing traditional towns and heritage districts. Archnet IJAR 1(3):153-166

Hall P (2002) Cities of tomorrow. Wiley, Oxford

Hawker R (2008) Traditional architecture of Arabian Gulf: building on desert tides. WIT Press, Cambridge

Howard E (1898) Garden cities of tomorrow. Swan Sonnenschein \& Co., Bath

Ibn Khaldun A (2004) The Muqaddimah: an introduction to history, translated by Franz Rosenthal. Princeton University Press, Princeton

Jaidah I, Bourennane M (2010) The history of Qatari architecture: from 1800-1950. Skira, Milan

Khalaf S (2006) The evolution of the Gulf city type, oil, and globalization. In: Fox JW, Mourtada-Sabbah N, Al-Mutawa M (eds) Globalization and the Gulf. Routledge, London, pp 244-265

Lauber W, Cisse L, Dembele M (2011) Architecture Dogon: traditional mud building in Mali. Hatje Cantz Verlag, Berlin

Leupen B, Grafe C, Kornig N, Lampe M, Zeeuw P (1997) Design and analysis. OIO Publishers, Rotterdam

Nagy S (2000) Dressing up downtown: urban development and government public image in Qatar. City Soc 12(1):125-147
Owens JE (1992) The city in the Greek and Roman world. Routledge, London Peterson JE (2008) Britain and state formation in the Gulf: the case of Abu Dhabi and Shaikh Zayid bin Khalifah. National Centre of Documentation and Research, Abu Dhabi

Petruccioli A (1998) Exoteric, polytheistic fundamentalist typology. In: Petruccioli A (ed) Typological processes and design theory, Aga Khan Program for Islamic architecture. Harvard University and Massachusetts Institute of Technology, Cambridge

Petruccioli A (2007) After Amnesia: learning from the Islamic Mediterranean Urban Fabric. ICAR, New Delhi

Philips S (2008) The christian home. Echo Library, Teddington

Qutub I (1985) Khasa'es Al-Numuou Al-Hadari fi Dowal Al-Khaleej Al-Arabi (Characteristics of Urban Growth in Arab Gulf States). Kazima Publications, Kuwait

Regette F (2003) Traditional domestic architecture of the Arab region: dissertation. American University of Sharjah, Sharjah

Salama AM (2006) A typological perspective: the impact of cultural paradigmatic shifts on the evolution of courtyard houses in Cairo. METU J Fac Archit 23(1):41-58

Salama AM, Wiedmann F (2013) Demystifying Doha: on architecture and urbanism in an emerging city. Routledge, London

Turner J (1976) Housing by people. Marion Boyars, London

Wiedmann F (2012) Post-oil urbanism in the Gulf: new evolutions in governance and the impact on urban morphologies. SVH Verlag, Stuttgart

Wiedmann F, Salama AM (2013) From pre-oil settlement to post-oil hub: the urban transformation of Doha. Archnet IJAR 7(2):146-159

Wiedmann F, Salama AM, Thierstein A (2012) Urban evolution of the city of Doha: an investigation into the impact of economic transformation on urban structures. METU J Fac Archit 29(2):35-61

\section{Submit your manuscript to a SpringerOpen ${ }^{\circ}$ journal and benefit from:}

- Convenient online submission

- Rigorous peer review

- Immediate publication on acceptance

- Open access: articles freely available online

- High visibility within the field

- Retaining the copyright to your article

Submit your next manuscript at $\boldsymbol{\nabla}$ springeropen.com 